
\title{
25 Research Square \\ Linking Industrial Point Sources to PFAS Contamination in Wells: Michigan Case Study
}

\section{Katarina Schulz}

University of Wisconsin-Milwaukee https://orcid.org/0000-0003-0123-1962

\section{Ryan Filbin}

University of Wisconsin-Milwaukee

Marcia R. Silva

University of Wisconsin-Milwaukee

Rebecca Klaper ( $\nabla$ rklaper@uwm.edu )

University of Wisconsin-Milwaukee

\section{Tracy Boyer}

University of Wisconsin-Milwaukee

\section{Research Article}

Keywords: PFAS, PFOS, contamination, wells, industry, point source

Posted Date: June 28th, 2021

DOI: https://doi.org/10.21203/rs.3.rs-473338/v1

License: (c) (i) This work is licensed under a Creative Commons Attribution 4.0 International License. Read Full License 


\section{Abstract}

In recent years, concern has grown over widespread environmental contamination of per- and polyfluoroalkyl substances (PFAS) in the environment and especially in drinking water. These manmade chemicals were first synthesized in the mid- $20^{\text {th }}$ century and contain thousands of individual species, some of which are still used today. A wide variety of industries use or have historically used PFAS in their products and processes. PFAS chemicals are recalcitrant by design and thus do not break down in the environment. Federal and state agencies have begun testing of drinking water and other media for PFAS in order to understand the extent of contamination and determine any necessary regulatory actions. Testing is expensive, however, and it would be beneficial to be able to prioritize wells for testing based on their likely vulnerability. This study presents a methodology for identifying locations of industrial sites likely to use PFAS, and uses Michigan's robust well testing data alongside industry and environmental factors to identify any spatial relationships that can be used to help prioritize testing of wells.

\section{Introduction}

Per- and polyfluorinated alkyl substances, or PFAS, are contaminants of emerging concern due to their widespread occurrence and recalcitrance in the environment, their tendency to bioaccumulate, and the wide variety of health effects associated with exposure at low concentrations (Lindstrom et al., 2011b). PFAS are known to enter the environment from both industrial and non-industrial waste dumping and effluent, airborne deposition via fumes, firefighting foam use, and disposal of PFAS-containing products in landfills where leaching can occur (Liu et al., 2017; Wang et al., 2014). They have been found extensively in both surface and groundwater drinking water sources water at concentrations ranging from non-detectible to hundreds of parts per trillion (ppt) (Boone et al., 2019). Substantial difficulty exists in predicting where high levels of contamination will occur and the causal sources. Identifying PFAS contamination in groundwater is complicated by the wide variety PFAS compounds in use, the lack of transparency and the variability in their use across multiple products, manufacturing processes, and industries. Although they are used in a diverse spectrum of consumer products and industrial processes, PFAS compounds are often only used in small amounts. Finally, lacking government regulation of PFAS chemicals results in limited reporting of use of these persistent chemicals and thus also results in difficulty funding and targeting monitoring PFAS contamination in the environment (KEMI, 2015).

Studies have shown that exposure to PFAS is associated with a variety of adverse health outcomes in humans, including hypertension, low birth weight, liver problems, thyroid problems, decreased vaccine response in children, and higher incidence of several kinds of cancer (Agency for Toxic Substances and Disease Registry (ATSDR), 2018; Grandjean et al., 2012; Granum et al., 2013; Kim et al., 2018; Nian et al., 2019; X. W. Zeng et al., 2019; Z. Zeng et al., 2019). Although concerns about PFAS chemicals have existed for over a decade, they have only recently become subject to regulation and these regulations are limited in the scope of the types of PFAS they address. In 2009, PFOS was listed as a persistent organic pollutant under the Stockholm Convention, and PFOA was added to the list in 2019 (Stockholm Convention, 2019, 2008). In 2019, USEPA issued interim recommendations for groundwater contaminated 
with PFOA and PFOS and is in early stage of risk assessment for both compounds in biosolids (EPA, Dec 2019).

Lack of information on industrial PFAS use results in the inability of groundwater managers and regulators to identify potential contamination sites efficiently or at a landscape scale for testing and monitoring. A few prior studies have looked at contamination sources of PFAS on various scales. Using data from USEPA's Third Unregulated Contaminant Monitoring Rule (UCMR 3), Hu et al (2016) looked for watershed-level correlation between PFAS contamination and the presence of wastewater treatment plants, military fire training areas, and fluoropolymer facilities that participated in the USEPA's stewardship program to phase out PFAS production (Hu et al., 2016). Associations were found between all types of sites and elevated PFAS concentrations in water. Guelfo et al (2018) created risk ranking for groundwater in the Providence, RI area based on industrial presence and aquifer vulnerability, listing Department of Defense sites, fluoropolymer manufacturers, landfills, and airports among the types of industrial sites contributing the most PFAS risk to water (Guelfo et al., 2018).

In this study we examined whether existing data about the location of industries known to use PFAS compounds can be used to predict future sites for monitoring. This differs from previous studies by incorporating all industry types found in the literature to use PFAS rather than just PFAS manufacturers, and incorporating extensive well testing data to spatially compare PFAS detections to possible point sources. Michigan was chosen as a study case as it began extensive statewide testing of drinking water wells for PFAS in 2018, and continued in 2019 with quarterly testing of wells that had tested at concentrations above $10 \mathrm{ppt}$ the previous year (State of Michigan, 2018). Few states have completed such widespread testing of drinking water sources. Nationwide testing under UCMR 3 has higher detection limits and covers around 5000 drinking water sources nationwide as opposed to over 1000 in Michigan from state-funded testing alone (USEPA, 2012). The goal of this study is to identify characteristics of wells, including proximity to industrial sites, type of bedrock, and well depth, that significantly impact the likelihood of PFAS contamination in order to help focus testing efforts on wells that share these characteristics in other areas.

\section{Methods}

\subsection{Michigan well and industry data}

Well testing data in Michigan was gathered from the Department of Environment, Great

Lakes, and Energy's (EGLE) report on PFAS testing using a Freedom of Information Act (FOIA) request submitted in February of 2020. This data identified wells based on their Water Supply Serial Number (WSSN) and did not include locations. This well test data was merged with the spatially explicit well data from Michigan's GIS portal that also identified wells using WSSNs and could thus be merged with the well testing data (Michigan Dept. of Environment, Great Lakes, 2019). The PFAS testing data from Michigan included 1126 sites, of which 1087 were included in this analysis after removal of surface water sources. 
The majority of wells were sampled between April and December of 2018, with one well sampled in September 2017 and seven wells sampled from January through September of 2019. Well water was tested using EPA's Method 537 Revised 1.1, which tests for 18 PFAS compounds. Concentrations were reported as a sum totals of PFOA and PFOS, and of all PFAS found; this study used the concentrations that included all 18 compounds. Among the well sites included in this study, 107 tested positive for PFAS with a range of total PFAS concentrations from $2 \mathrm{ppt}$ to $1828 \mathrm{ppt}$ and an average concentration of 28.794 ppt, whereas 974 sites did not contain PFAS at detectable levels. Notably, the site with a concentration of $1828 \mathrm{ppt}$ was an outlier, as the next highest concentration was $72 \mathrm{ppt}$.

Industries that use or are sources of PFAS were identified in a literature search. Prior studies on point sources as well as studies analyzing products that contain PFAS led to the inclusion of the industry groups listed in Table 1 with their relevant NAICS codes and studies that indicated their PFAS use. Briefly, PFAS have a wide variety of industrial uses including nonstick coatings, metal finishing, fabric finishing, plastics manufacturing, lubricants, and pesticides (Buck et al., 2011; Glüge et al., 2020; Guelfo et al. 2018; Herzke et al. 2012; Kissa, 2001; Nascimento et al., 2018). Studies have also indicated PFAS use in medical devices, electronics, cleaning products, and photographic film processes (Clara et al., 2008; Gosetti et al., 2018; Lin et al., 2009; Xie et al., 2013). Studies indicating PFAS contamination at military sites and landfills are also well documented (Guelfo et al., 2018; Hu et al., 2016; Liu et al., 2017; Oliaei et al., 2013). Industrial sites for Michigan were spatially located using the NAICS codes listed in Tables 1 and 2, and the USEPA's Enforcement and Compliance History Online (ECHO) facility search (USEPA, 2018). Sites include both current and historic facilities as of 8 June, 2020. Industrial and well locations were mapped using a geographic information system (GIS), ESRI ArcMap version 10.7 (Redlands, CA, USA).

\subsection{Linking industrial sites to PFAS contamination}

Previous studies have shown that a $0.5 \mathrm{~km}$ radius buffer around a groundwater source and potential contaminants is a sufficiently sized area to study significant correlation between land use and contamination. Johnson and Belitz (2009) found that a 500m circle, though a highly simplified model, was sufficient to show correlation between volatile organic compound (VOC) contamination of groundwater and urban land use (Johnson and Belitz, 2009). Lindstrom et al. (2011a) found that $82 \%$ of wells within $0.5 \mathrm{~km}$ of fields that received contaminated biosolids tested positive for PFAS (Lindstron et al., 2011a). Finally, impervious surfaces are known to cause rapid runoff that carries heavy loads pollutants into waterways, which can ultimately impact groundwater sources (Frazer, 2005). Use of PFAS at airports and other places where AFFF foams may be used in paved areas could contribute to pollution from such runoff (Awad et al, 2011). One study has linked landfill, military, and PFAS-producing facilities to drinking water contamination on a hydrologic unit basis using UCMR3 testing data, but did not include industries that use PFAS or link specific sites to contamination (Hu et al. 2016). Based on these studies, we hypothesized that location within the $0.1 \mathrm{~km}, 0.5 \mathrm{~km}$, and $1 \mathrm{~km}$ buffer zones of PFAS-related industrial sites, Coldwater Shale bedrock type, well-drained soils, and impervious land cover would show a significant positive correlation with PFAS detection in wells, whereas well depth would show a significant 
negative correlation with PFAS detections. Coldwater Shale bedrock type was chosen because it was the most common bedrock type at contaminated well sites (35\%). Based on previous literature and the prevalence of industries within the buffer zones (as indicated in Table 2), we also hypothesized specifically that the number and percentage of current and historic electroplating facilities, airports, and landfills within the buffer zones would be positively correlated with PFAS detections in wells (Awad et al., 2011; Hepburn et al., 2019; Milley et al., 2018). To test for effects of industry presence on PFAS well contamination in Michigan, we used a maximum likelihood method, Probit analysis and Moran's I as described below.

\subsubsection{Probit Models}

Using a Probit function, the spatial siting of industries and the bedrock characteristics were used to predict the probability of a positive well test for PFAS. To test for a relationship between industry presence on PFAS detections in wells, buffer zones of $0.1 \mathrm{~km}, 0.5 \mathrm{~km}$, and $1 \mathrm{~km}$ were constructed around each well tested for PFAS. In this study, industry presence within these buffer zones was analyzed as an effect on detection and non-detection in wells while controlling for other factors such as bedrock type, land cover, and well depth. Wells were given a value of 0 if PFAS were not detected (ND), and given a value of 1 if any level of PFAS were detected. A value of 1 was given for wells located within the Coldwater Shale bedrock formation, and a value of 0 given for wells within all other bedrock formation types. Coldwater Shale was selected as it is the most common bedrock formation for wells with detected levels of PFAS. Well depth was based on the numerical value of the well's depth, in feet, and well depth squared is the squared value of the depth of each well in feet squared. A value of 1 was given for wells with a "developed, low intensity" land cover classification (NLCD code 22), and a value of 0 given for wells with any other land cover classification. A value of 1 was given for wells with "well drained", "excessively drained", or "somewhat excessively drained" soil drainage classifications. A value of 0 was given for wells with any other soil drainage classification. A few specific industries were chosen as separate variables because they were present at the highest numbers within the well buffers (see Table 2): landfill, electroplating, metal foil manufacture, and airport sites. All models were estimated as either percent, meaning the total percentage of sites within the given radius $(0.5 \mathrm{~km}$ or $1 \mathrm{~km})$ of a well that belong to the specific industry, or raw number, which is the number of industry sites classified as the specific industry within the given radius of a well. The percentage of "all others", which includes all the industry sites included in the analysis apart from the specified industries just outlined, was also estimated in each model. Lastly, a variable was assigned for the total number of quarters within the past three years that industry sites in a given radius had failed to comply with EPA environmental standards, with a maximum value of 12 . A summary of the variables used in the Probit models is shown in Table 1.

Four Probit models were considered to test the effect of land use and type on the probability of detection, such as the number and types of industries within a certain buffer of the well, bedrock, land cover, soil type, well depth, and well depth squared on the probability of PFAS detection in a well using the equation as follows 
where the dependent variable is assigned values of 0 or 1 . The four models separate the amount/percent and type of industries found within each buffer from the data found within other buffers. In this study, the detection of PFAS pollution at well sites is the dependent variable where a value of 1 indicates any detected level of PFAS pollution, otherwise the variable takes a value of 0 . The limit of detection was 2 or $4 \mathrm{ppt}$ depending on the analyte (AECOM 2018). Several independent variables were included in the Probit regression model: number of industrial sites (\#sites) within each spatial buffer of the wells $(0.1 \mathrm{~km}$, $0.5 \mathrm{~km}, 1 \mathrm{~km}$ ), well depth in feet (depth), the percentage of sites within $1 \mathrm{~km}$ of specific industry types thought to be more likely to contribute to contamination (airports, landfills, and electroplaters) (percentindustry), and the total number of quarters in which an industrial site had USEPA violations in the past three years ${ }^{[1]}$ (\#violations). The Probit regression model in Equation 1 was analyzed using IBM SPSS Statistics 26 , with statistically significant variables having a $p$-value no greater than 0.10 . Results are in sections 2.3.1 and 2.3.2 (IBM Corp., 2019).

\subsubsection{Cluster analysis}

A negative Local Moran's I Index was performed to identify any spatial correlation between detections of PFAS in wells in relation to each other, separate from industry presence. This analysis indicates spatial outliers, where the data at one location is independent of the data at nearby locations (Anselin, 1995). In this study, spatial outliers indicate that the level of PFAS pollution at one well is independent of the level of PFAS pollution at nearby wells. A positive Local Moran's I Index value indicates spatial clustering, where the data at one location is similar to the data at nearby locations. In this study, spatial clusters indicate that the level of PFAS pollution at one well significantly resembles the levels at nearby wells. Spatial clustering defined by high-high (high values near other high values) and low-low (low values near other high values) clusters. High-high PFAS clusters indicate potential hotspots of PFAS pollution, whereas low-low clusters indicate areas of low pollution levels. Spatial outliers are represented by lowhigh (low value at one location near high values at nearby locations) and high-low outliers (high value at one location near low values at nearby locations). Local Moran's I results are significant in this study if the $p$-value is no greater than 0.05 . The Index values $l_{i}$ range from -1 to +1 and are determined using the following equations:

$$
I_{i}=\frac{x_{i}-\bar{X}}{S_{i}^{2}} \sum_{j=1, j \neq 1}^{n} w_{i, j}\left(x_{j}-\bar{X}\right)
$$

where $x_{i}$ is the level of PFAS pollution at well site $i, X$ is the mean PFAS level across all wells, and $w_{i, j}$ is the spatial weight between well sites $i$ and $j$, and 
$S_{i}^{2}=\frac{\sum_{j=1, j \neq 1}^{n}\left(x_{j}-\bar{X}\right)^{2}}{n-1}$

where $n$ is the total number of well sites with detected levels of PFAS. An index value of -1 indicates negative correlation between positive PFAS detections or an outlier, a value of 0 indicates no correlation, and a value of +1 indicates a positive correlation or cluster.

\section{Results And Discussion}

\subsection{Industrial and well sites}

Using the NAICS codes listed in Table 3, 2696 relevant industry sites were identified in Michigan. Figure 1 shows the number of industrial sites present in each county. Among the well sites included in this study, 107 tested positive for PFAS with an average concentration of $28.794 \mathrm{ppt}$, whereas 974 sites did not contain PFAS at detectable levels. No identified industrial sites fell within $0.1 \mathrm{~km}$ of a well that tested positive for PFAS, and only two industrial sites fell within $0.1 \mathrm{~km}$ of any well identified in this study. A total of eight industrial sites were located within $0.5 \mathrm{~km}$ of wells that tested positive for PFAS, three of which were landfills. Other industries within half a kilometer of PFAS wells were metal coating, metal foil, plastics manufacturing, paper mill, and oil and grease manufacturing facilities. Table 3 summarizes the industry sites found within each radius. Twenty-six industrial sites fall within $1 \mathrm{~km}$ of wells that tested positive for PFAS; of these sites, eight were landfills, six were metal foil manufacturing, three were airport sites, two were paper mills, two were plastics manufacturing, one electroplating, one metal coating, one commercial printing, one oil and grease manufacturing, and one miscellaneous textiles facility. The totals for $1 \mathrm{~km}$ are inclusive of the sites found within $0.5 \mathrm{~km}$.

\subsection{Linking industrial sites to PFAS contamination}

We hypothesized that the presence of the selected industries would have significant positive correlations with detections of PFAS in wells, as would the depth of the well, and that greater significance would be attributed to facilities belonging to industries already shown to contribute to PFAS contamination (i.e., airports, landfills, electroplaters) and to major facilities. In addition to likelihood of contamination decreasing with well depth, we also hypothesized that as the depth of the well increased, the likelihood of contamination would further decrease, indicated by well depth squared. Because of the lack of industrial sites within $0.1 \mathrm{~km}$ of wells, no Probit model was estimated for that buffer, but the model was estimated using both the number of each industry in the buffers as well as the percentage each industry in the buffers for $0.5 \mathrm{~km}$ and $1.0 \mathrm{~km}$. It should be noted that in the case of the $0.5 \mathrm{~km}$ buffers, electroplating was replaced with metal foil due to limited values for metal foil in the $0.5 \mathrm{~km}$ buffers. Omnibus Tests determined that our four Probit models were all significant at greater than $99 \%$ confidence. The model results are shown in Tables 4 and 5 . 


\subsubsection{Probit models, $1 \mathrm{~km}$}

The $1.0 \mathrm{~km}$ buffer models both showed that well depth, well depth squared, and well-drained soil were significantly likely to increase the probability of PFAS detection at greater than $99 \%$ confidence level (Table 4). In both cases, well depth positively affected the likelihood of detection, while well depth squared had a negative effect. This indicates that the likelihood of PFAS detection increases with deeper wells, but that the rate of increase declines as depth increases. The positive effect of greater well depth on the probability of PFAS detection runs counter to our hypothesized relationship. One explanation for this could be that wells in vulnerable areas are dug deeper as a preventative measure, but further study is necessary to confirm this. There was a positive relationship between percentage of electroplaters, along with percentage of all other industry and the likelihood of PFAS detection in the $1.0 \mathrm{~km}$ model, which corroborates our hypothesis.

The relatively high number of metal foil sites (compared to the other industries included in this study) within $1 \mathrm{~km}$ of positive-detect wells is surprising. Although this industry appeared on a list of PFAS-using industries created by the Minnesota Pollution Control Agency (MPCA), it has not yet become an industry of focus across literature examining PFAS pollution. Additional research on metal foil practices could help confirm if this industry contributes significantly to PFAS contamination in wells near facilities.

\subsubsection{Probit models, $0.5 \mathrm{~km}$}

For both Probit models estimated at the buffer size of $0.5 \mathrm{~km}$, well depth, well depth squared, and welldrained soil showed significant effects on likelihood to detect positive PFAS levels (Table 5). Similar the $1.0 \mathrm{~km}$ models, well depth and well-drained soil had a positive effect while well depth squared had a negative effect on the probability of detection. It appears based on these analyses that more permeable soil near a well is more important than presence of specific industry types when predicting PFAS contamination in wells. Despite the higher numerical value of metal foil sites within the $0.5 \mathrm{~km}$ buffers compared to other sites, the number and percent metal foil sites did not prove significant in this model. This is likely due to the number of metal foil sites still being low, despite being higher than other industry types. Percent and number of landfill sites were also not significant at this level, along with bedrock type, land cover, and quarters with violations.

\subsubsection{Cluster analysis}

A local Moran's I test examining clusters and outliers of high versus low concentrations of PFAS within wells that tested positive showed eight low-high outliers, three high-high clusters, and one high-low outlier all concentrated in southwest Michigan. A map of clusters and outliers can be seen in Figure 2. It is interesting to note that the high-high clusters and both types of outliers are predominantly located in Kalamazoo and Allegan counties, both of which have relatively high numbers of industry sites compared to other counties. About half of the industrial sites in these counties were landfills, which corresponds to 
the percentage of landfills compared to total industrial sites in the state as a whole. In these two counties, however, only one of the landfills ( $1.6 \%$ of total landfills) was flagged as actively operating, whereas more than $4 \%$ of the state's total landfills were labeled active. A higher percentage of inactive landfills may indicate older landfills. Because landfills were not required to be lined until the Resource Conservation and Recovery Act of 1976, older landfills are more likely to cause leaching of contaminants into groundwater (Congress, 1976). Thus, a higher proportion of inactive landfills in Kalamazoo and Allegan counties may explain the clustering found in these counties from the Moran's I test. The presence of outliers, or wells with high concentrations having a significant number of wells with low concentrations nearby and vice versa, could be explained by landfill leachate permeating wells to different degrees. Further study of wells in this region, the groundwater flow near these wells, and their proximity to landfills could help explain the outliers found in this study. In addition to the clusters and outliers in southwest Michigan, ten low-low clusters were identified throughout the state. All other clusters and outliers determined using Local Moran's I have $p$-values exceeding the 0.05 threshold, and are not statistically significant to include in the study. Table 7 identifies the location of statistically significant Moran's I results, the Index values, and Z-scores.

\section{Conclusions}

Overall, this study underscores the difficulty of tying industrial presence to PFAS contamination in drinking water wells as a means of targeting groundwater testing at a landscape scale. Spatially, the Moran's I results pointed to landfills as a possible smoking gun for PFAS detection, due to a high portion of clusters coinciding with counties that host a high number of inactive landfills, but the more detail, sitespecific probit model did not show significance between landfill presence and positive PFAS detections in wells. Future research could investigate the relationship between age of landfills and detections of PFAS, as this data set did not include landfill age. Although multiple variables were investigated in our predictive probit models to predict PFAS well contamination, the only factors that proved significant in all models were well depth, well depth squared, and soil type. The positive correlation found between well depth and PFAS detection contradicted our hypothesis, and a possible explanation for this is wells being dug deeper in vulnerable areas. The recalcitrance of PFAS prevents them from breaking down, and this allows them to eventually reach greater depths. It was found in one of the $1.0 \mathrm{~km}$ models that the higher the percentage of electroplating facilities within $1 \mathrm{~km}$ of the well compared to total industries studied, the more likely a well was contaminated with PFAS. Based on these results, it can be stated that wells constructed in well-drained soil and with electroplating facilities within a kilometer are likelier to be contaminated with PFAS. This information can be useful for identifying wells to prioritize for testing, but additional predictive parameters would be helpful for more accurate targeting. Future research in this area should consider additional parameters that may lead to trends in PFAS well contamination, such as slope, elevation, and groundwater flow direction surrounding wells.

\section{Declarations}




\section{Ethical Approval and Consent to Participate}

Not applicable.

\section{Consent for Publication}

Not Applicable

\section{Availability of Data and Materials}

The datasets used and/or analyzed during the current study are available from the corresponding author on reasonable request.

\section{Competing Interests}

The authors have no relevant financial or non-financial interests to disclose.

\section{Funding Source}

The research leading to these results received funding from the National Science Foundation via the Industry/University Cooperative Research Center on Water Equipment \& Policy under Grant Agreement No 1540032

\section{Author Contributions}

$\mathrm{KS}, \mathrm{RF}, \mathrm{RK}, \mathrm{MS}$, and TB contributed to the study conception and design. Material preparation, data collection and analysis were performed by KS, RF and TB. The first draft of the manuscript was written by $\mathrm{KS}$ and all authors commented on previous versions of the manuscript. KS, RF, RK, MS, and TB read and approved the final manuscript.

\section{Acknowledgements}

National Science Foundation Industry/University Cooperative Research Center on Water Equipment \& Policy located at University of Wisconsin-Milwaukee (IIP-1540032) and Marquette University (IIP-

1540010).

\section{References}

AECOM, 2018. 2018 PFAS Sampling of Public Water Supplies in Michigan, Appendix A: Quality Assurance and Quality Control Summary Analytical.

Agency for Toxic Substances and Disease Registry (ATSDR), 2018. Toxicological Profile for Per- and Polyfluoroalkyl Substances: Draft for public comment. 
Anselin, L., 1995. Local Indicators of Spatial Association-LISA. Geogr. Anal.

https://doi.org/10.1111/j.1538-4632.1995.tb00338.x

Awad, E., Zhang, X., Bhavsar, S.P., Petro, S., Crozier, P.W., Reiner, E.J., Fletcher, R., Tittlemier, S.A., Braekevelt, E., 2011. Long-Term Environmental Fate of Perfluorinated Compounds after Accidental Release at Toronto Airport. Environ. Sci. Technol. 45, 8081-8089. https://doi.org/10.1021/es2001985

Boone, J.S., Vigo, C., Boone, T., Byrne, C., Ferrario, J., Benson, R., Donohue, J., Simmons, J.E., Kolpin, D.W., Furlong, E.T., Glassmeyer, S.T., 2019. Per- and polyfluoroalkyl substances in source and treated drinking waters of the United States. Sci. Total Environ. 653, 359-369.

https://doi.org/10.1016/j.scitotenv.2018.10.245

Buck, R.C., Franklin, J., Berger, U., Conder, J.M., Cousins, I.T., Voogt, P. de, Jensen, A.A., Kannan, K., Mabury, S.A., van Leeuwen, S.P.J., 2011. Perfluoroalkyl and polyfluoroalkyl substances in the environment:

Terminology, classification, and origins. Integr. Environ. Assess. Manag. 7, 513-541.

https://doi.org/10.1002/ieam.258

Clara, M., Scheffknecht, C., Scharf, S., Weiss, S., Gans, O., 2008. Emissions of perfluorinated alkylated substances (PFAS) from point sources - Identification of relevant branches. Water Sci. Technol. 58, 5966. https://doi.org/10.2166/wst.2008.641

Congress, U. S. (1976). Resource Conservation and Recovery Act. Public Law, 94, 580.

EPA, 2018. Enforcement and Compliance History Online. https://doi.org/https://echo.epa.gov/

Frazer, L., 2005. Paving paradise: The peril of impervious surfaces. Environ. Health Perspect. https://doi.org/10.1289/ehp.113-a456

Glüge, J., Scheringer, M., Cousins, I.T., DeWitt, J.C., Goldenman, G., Herzke, D., Lohmann, R., Ng, C.A., Trier, X., Wang, Z., 2020. An overview of the uses of per- and polyfluoroalkyl substances (PFAS). Environ. Sci. Process. Impacts. https://doi.org/10.1039/d0em00291g

Gosetti, F., Bolfi, B., Robotti, E., Manfredi, M., Binotti, M., Ferrero, F., Bona, G., Marengo, E., 2018. Study of endocrine disrupting compound release from different medical devices through an on-line SPE UHPLCMS/MS method. Anal. Chim. Acta 1042, 141-154. https://doi.org/10.1016/J.ACA.2018.07.028

Grandjean, P., Andersen, E.W., Budtz-Jørgensen, E., Nielsen, F., Mølbak, K.R., Weihe, P., Heilmann, C., 2012. Serum vaccine antibody concentrations in children exposed to perfluorinated compounds. JAMA - J. Am. Med. Assoc. 307, 391-397. https://doi.org/10.1001/jama.2011.2034

Granum, B., Haug, L.S., Namork, E., Stølevik, S.B., Thomsen, C., Aaberge, I.S., Van Loveren, H., Løvik, M., Nygaard, U.C., 2013. Pre-natal exposure to perfluoroalkyl substances may be associated with altered vaccine antibody levels and immune-related health outcomes in early childhood. J. Immunotoxicol. 10, 373-379. https://doi.org/10.3109/1547691X.2012.755580 
Guelfo, J.L., Marlow, T., Klein, D.M., Savitz, D.A., Frickel, S., Crimi, M., Suuberg, E.M., 2018. Evaluation and management strategies for per-and polyfluoroalkyl substances (PFASs) in drinking water aquifers:

Perspectives from impacted U.S. northeast communities. Environ. Health Perspect.

https://doi.org/10.1289/EHP2727

Hepburn, E., Madden, C., Szabo, D., Coggan, T.L., Clarke, B., Currell, M., 2019. Contamination of groundwater with per- and polyfluoroalkyl substances (PFAS) from legacy landfills in an urban redevelopment precinct. Environ. Pollut. 248, 101-113. https://doi.org/10.1016/j.envpol.2019.02.018

Herzke, D., Olsson, E., Posner, S., 2012. Perfluoroalkyl and polyfluoroalkyl substances (PFASs) in consumer products in Norway - A pilot study. Chemosphere 88, 980-987.

https://doi.org/10.1016/j.chemosphere.2012.03.035

Houtz, E.F., Higgins, C.P., Field, J.A., Sedlak, D.L., 2013. Persistence of perfluoroalkyl acid precursors in AFFF-impacted groundwater and soil. Environ. Sci. Technol. 47, 8187-8195.

https://doi.org/10.1021/es4018877

Hu, X.C., Andrews, D.Q., Lindstrom, A.B., Bruton, T.A., Schaider, L.A., Grandjean, P., Lohmann, R., Carignan, C.C., Blum, A., Balan, S.A., Higgins, C.P., Sunderland, E.M., 2016. Detection of Poly- and Perfluoroalkyl Substances (PFASs) in U.S. Drinking Water Linked to Industrial Sites, Military Fire Training Areas, and Wastewater Treatment Plants. Environ. Sci. Technol. Lett. 3, 344-350.

https://doi.org/10.1021/acs.estlett.6b00260

IBM Corp., 2019. IBM SPSS Statistics for Windows, Version 26.0. 2019.

Johnson, T.D., Belitz, K., 2009. Assigning land use to supply wells for the statistical characterization of regional groundwater quality: Correlating urban land use and VOC occurrence. J. Hydrol. 370, $100-108$. https://doi.org/10.1016/j.jhydrol.2009.02.056

KEMI, 2015. Occurrence and use of highly fluorinated substances and alternatives. Report from a government assignment 27-51.

Kim, M.J., Moon, S., Oh, B.-C., Jung, D., Ji, K., Choi, K., Park, Y.J., 2018. Association between perfluoroalkyl substances exposure and thyroid function in adults: A meta-analysis. PLoS One 13, e0197244.

https://doi.org/10.1371/journal.pone.0197244

Kissa, E., 2001. Fluorinated Surfactants and Repellants, Second Edi. ed. Taylor \& Francis, New York.

Kotthoff, M., Müller, J., Jürling, H., Schlummer, M., Fiedler, D., 2015. Perfluoroalkyl and polyfluoroalkyl substances in consumer products. Environ. Sci. Pollut. Res. 22, 14546-14559.

https://doi.org/10.1007/s11356-015-4202-7

Lin, A.Y.C., Panchangam, S.C., Lo, C.C., 2009. The impact of semiconductor, electronics and optoelectronic industries on downstream perfluorinated chemical contamination in Taiwanese rivers. Environ. Pollut. 
Lindstrom, A.B., Strynar, M.J., Delinsky, A.D., Nakayama, S.F., McMillan, L., Libelo, E.L., Neill, M., Thomas, L., 2011a. Application of WWTP biosolids and resulting perfluorinated compound contamination of surface and well water in Decatur, Alabama, USA. Environ. Sci. Technol. 45, 8015-8021. https://doi.org/10.1021/es1039425

Lindstrom, A.B., Strynar, M.J., Libelo, E.L., 2011b. Polyfluorinated compounds: Past, present, and future. Environ. Sci. Technol. 45, 7954-7961. https://doi.org/10.1021/es2011622

Liu, Z., Lu, Y., Wang, P., Wang, T., Liu, S., Johnson, A.C., Sweetman, A.J., Baninla, Y., 2017. Pollution pathways and release estimation of perfluorooctane sulfonate (PFOS) and perfluorooctanoic acid (PFOA) in central and eastern China. Sci. Total Environ. https://doi.org/10.1016/j.scitotenv.2016.12.085

Lo, J., Gilljam, fstedt, Leonel, J., Cousins, I.T., Benskin, J.P., 2015. Is Ongoing Sulfluramid Use in South America a Significant Source of Perfluorooctanesulfonate (PFOS)? Production Inventories, Environmental Fate, and Local Occurrence. https://doi.org/10.1021/acs.est.5b04544

Michigan Dept. of Environment, Great Lakes, and E., 2019. GIS Open Data, State of Michigan [WWW Document]. URL https://gis-michigan.opendata.arcgis.com/datasets/egle::water-wellssouthwestmichigan

Milley, S.A., Koch, I., Fortin, P., Archer, J., Reynolds, D., Weber, K.P., 2018. Estimating the number of airports potentially contaminated with perfluoroalkyl and polyfluoroalkyl substances from aqueous film forming foam: A Canadian example. J. Environ. Manage. 222, 122-131.

https://doi.org/10.1016/j.jenvman.2018.05.028

Nascimento, R.A., Nunoo, D.B.O., Bizkarguenaga, E., Schultes, L., Zabaleta, I., Benskin, J.P., Spanó, S., Leonel, J., 2018. Sulfluramid use in Brazilian agriculture: A source of per- and polyfluoroalkyl substances (PFASs) to the environment. Environ. Pollut. 242, 1436-1443.

https://doi.org/10.1016/j.envpol.2018.07.122

Nian, M., Li, Q.Q., Bloom, M., Qian, Z. (Min), Syberg, K.M., Vaughn, M.G., Wang, S.Q., Wei, Q., Zeeshan, M., Gurram, N., Chu, C., Wang, J., Tian, Y.P., Hu, L.W., Liu, K.K., Yang, B.Y., Liu, R.Q., Feng, D., Zeng, X.W., Dong, G.H., 2019. Liver function biomarkers disorder is associated with exposure to perfluoroalkyl acids in adults: Isomers of C8 Health Project in China. Environ. Res. 172, 81-88.

https://doi.org/10.1016/j.envres.2019.02.013

Oliaei, F., Kriens, D., Weber, R., Watson, A., 2013. PFOS and PFC releases and associated pollution from a PFC production plant in Minnesota (USA). Environ. Sci. Pollut. Res. https://doi.org/10.1007/s11356012$1275-4$

Qualtrics, 2019. Qualtrics. 
Schaider, L.A., Balan, S.A., Blum, A., Andrews, D.Q., Strynar, M.J., Dickinson, M.E., Lunderberg, D.M., Lang, J.R., Peaslee, G.F., 2017. Fluorinated Compounds in U.S. Fast Food Packaging. Environ. Sci. Technol. Lett. 4, 105-111. https://doi.org/10.1021/acs.estlett.6b00435

State of Michigan, 2018. PFAS Response - Statewide Testing Initiative [WWW Document]. URL https://www.michigan.gov/pfasresponse/0,9038,7-365-86510_87918-464299--,00.html (accessed 8.10.20).

Stockholm Convention, 2019. SC-9 / 12: Listing of perfluorooctanoic acid ( PFOA ), its salts and PFOArelated compounds $2-4$.

Stockholm Convention, 2008. Listing of perfluorooctane sulfonic acid (PFOS), its salts and perfluorooctane sulfonyl fluoride (PFOSF) in Annex B of the Stockholm Convention on Persistent Organic Pollutants. Unep/Pops/Cop.4/17 15-18.

USEPA, 2012. The Third Unregulated Contaminant Monitoring Rule.

Wang, Z., Cousins, I.T., Scheringer, M., Buck, R.C., Hungerbühler, K., 2014. Global emission inventories for C4-C14 perfluoroalkyl carboxylic acid (PFCA) homologues from 1951 to 2030, Part I: production and emissions from quantifiable sources. Environ. Int. 70, 62-75.

https://doi.org/10.1016/J.ENVINT.2014.04.013

Xie, S., Wang, T., Liu, S., Jones, K.C., Sweetman, A.J., Lu, Y., 2013. Industrial source identification and emission estimation of perfluorooctane sulfonate in China. Environ. Int. 52, 1-8.

https://doi.org/10.1016/J.ENVINT.2012.11.004

Zeng, X.W., Bloom, M.S., Dharmage, S.C., Lodge, C.J., Chen, D., Li, S., Guo, Y., Roponen, M., Jalava, P., Hirvonen, M.R., Ma, H., Hao, Y.T., Chen, W., Yang, M., Chu, C., Li, Q.Q., Hu, L.W., Liu, K.K., Yang, B.Y., Liu, S., Fu, C., Dong, G.H., 2019. Prenatal exposure to perfluoroalkyl substances is associated with lower hand, foot and mouth disease viruses antibody response in infancy: Findings from the Guangzhou Birth Cohort Study. Sci. Total Environ. 663, 60-67. https://doi.org/10.1016/j.scitotenv.2019.01.325

Zeng, Z., Song, B., Xiao, R., Zeng, G., Gong, J., Chen, M., Xu, P., Zhang, P., Shen, M., Yi, H., 2019. Assessing the human health risks of perfluorooctane sulfonate by in vivo and in vitro studies. Environ. Int. 126, 598610. https://doi.org/10.1016/J.ENVINT.2019.03.002

\section{Tables}

Table 1: Industry groups included in this study, the associated NAICS codes for specific industries within those groups, and the sources that led to the inclusion of those industries. 


\begin{tabular}{|c|c|c|}
\hline Industry Type & NAICS Codes & Source(s) \\
\hline Textiles and Carpets & $\begin{array}{l}\text { 313210, 313310, } \\
313320,314110 \\
314999,316110\end{array}$ & $\begin{array}{l}\text { Glüge et al. 2020; Guelfo et al. 2018; Herzke } \\
\text { et al. 2012; Kotthoff et al. 2015; }\end{array}$ \\
\hline Chemical Manufacturing & $\begin{array}{l}325199,325320 \\
325622,325612,424690\end{array}$ & $\begin{array}{l}\text { Glüge et al. 2020; Guelfo et al. 2018; Hu et } \\
\text { al. 2016; Nascimento et al. } 2018\end{array}$ \\
\hline Paper Products & $\begin{array}{l}322121,322219, \\
322220,323111, \\
323120,\end{array}$ & $\begin{array}{l}\text { Glüge et al. 2020; Guelfo et al. 2018; Herzke } \\
\text { et al. 2012; Schaider et al. } 2017\end{array}$ \\
\hline $\begin{array}{l}\text { Plastics/ Rubber } \\
\text { Manufacturing }\end{array}$ & $\begin{array}{l}325211,326112 \\
326113\end{array}$ & $\begin{array}{l}\text { Glüge et al. 2020; Guelfo et al. 2018; } \\
\text { Schaider et al. } 2017\end{array}$ \\
\hline $\begin{array}{l}\text { Grease, Oil, and } \\
\text { Lubricant-related } \\
\text { industries }\end{array}$ & $\begin{array}{l}324110,324191 \\
333318,336310\end{array}$ & Glüge et al. 2020; Guelfo et al. 2018; \\
\hline AFFF Use & 488119,928110 & $\begin{array}{l}\text { Glüge et al. 2020; Guelfo et al. 2018; Hu et } \\
\text { al. 2016; Milley et al. } 2018\end{array}$ \\
\hline $\begin{array}{l}\text { Electroplating/Metal } \\
\text { Finishing }\end{array}$ & 332813,332999 & Glüge et al. 2020; Guelfo et al. 2018; \\
\hline Dry Cleaners & 812310,812320 & Clara et al. 2008; Glüge et al. 2020 \\
\hline $\begin{array}{l}\text { Paint and Coating } \\
\text { Manufacturing }\end{array}$ & 325510 & Glüge et al. 2020; Herzke et al. 2012; \\
\hline $\begin{array}{l}\text { Medical } \\
\text { Instruments/Apparatuses }\end{array}$ & 333249 & Glüge et al. 2020; Gosetti et al. 2018 \\
\hline $\begin{array}{l}\text { Photographic } \\
\text { Film/Chemicals }\end{array}$ & 325992 & Glüge et al. 2020; Xie et al. 2013 \\
\hline Landfills & 562212 & $\begin{array}{l}\text { Guelfo et al. 2018; Hepburn et al. 2019; Hu } \\
\text { et al. 2016; Liu et al. 2017; Oliaei et al. } 2013\end{array}$ \\
\hline Electronics & 3344 (all) & Glüge et al. 2020; Lin et al. 2009 \\
\hline
\end{tabular}

Table 2: Summary statistics of variables used in Probit regression analysis $-0.5 \mathrm{~km}$ and $1 \mathrm{~km}$ buffers $(\mathrm{N}=1081)$. 
Variable

$\begin{array}{ll}\text { Variable } & \text { Variable } \\ \text { Description }\end{array}$

Model(s) Expected Mean/(sd) Min. Max.

\section{Effect on}

Dependent

Variable

$(+/-)$

\begin{tabular}{|c|c|c|c|c|c|c|c|}
\hline Detect & $\begin{array}{l}0 \text { if non-detect } \\
\text { (ND), } 1 \text { if detect } \\
\text { (D) }\end{array}$ & & All & $\mathrm{n} / \mathrm{a}$ & 0.099 & 0 & 1 \\
\hline \multirow[t]{2}{*}{ Bedrock } & $\begin{array}{l}0 \text { if other } \\
\text { bedrock type, } 1 \\
\text { if "Coldwater } \\
\text { Shale" }\end{array}$ & & All & + & $0.31(0.46)$ & 0 & 1 \\
\hline & formation & & & & & & \\
\hline Welldepth & Well depth (ft.) & All & & - & $\begin{array}{l}173.90 \\
(107.76)\end{array}$ & 21 & 815 \\
\hline \multirow[t]{2}{*}{ Welldepthsq } & \multirow{2}{*}{$\begin{array}{l}\text { Well depth } \\
\text { squared }\end{array}$} & \multirow[t]{2}{*}{ All } & & - & 4184.86 & 576 & 664225 \\
\hline & & & & & $(60263.90)$ & & \\
\hline \multirow[t]{2}{*}{ Landcover } & $\begin{array}{l}0 \text { if other land } \\
\text { classification, } 1 \\
\text { if }\end{array}$ & & All & + & $0.23(0.42)$ & 0 & 1 \\
\hline & $\begin{array}{l}\text { "developed, low } \\
\text { intensity" (NLCD } \\
\text { code 22) }\end{array}$ & & & & & & \\
\hline Soildrainage & $\begin{array}{l}0 \text { if other } \\
\text { drainage } \\
\text { classification, } 1 \\
\text { if "well drained", } \\
\text { "excessively } \\
\text { drained", or } \\
\text { "somewhat } \\
\text { excessively } \\
\text { drained" }\end{array}$ & & All & + & $0.74(0.44)$ & 0 & 1 \\
\hline Percentlandfill & $\begin{array}{l}\text { Percent of sites } \\
\text { as landfills } \\
\text { within } 0.5 \mathrm{~km} \text { of } \\
\text { wells }\end{array}$ & 1 & & + & $0.01(0.09)$ & 0 & 1 \\
\hline Percentmetalfoil & $\begin{array}{l}\text { Percent of sites } \\
\text { as metal foil } \\
\text { within } 0.5 \mathrm{~km} \text { of } \\
\text { wells }\end{array}$ & & 1 & + & $0.01(0.07)$ & 0 & 1 \\
\hline Landfill & $\begin{array}{l}\text { Number of sites } \\
\text { as landfills } \\
\text { within } 0.5 \mathrm{~km} \text { of }\end{array}$ & & 2 & + & $0.01(0.16)$ & 0 & 3 \\
\hline
\end{tabular}


wells

\begin{tabular}{|c|c|c|c|c|c|c|}
\hline Metalfoil & $\begin{array}{l}\text { Number of sites } \\
\text { as metal foil } \\
\text { within } 0.5 \mathrm{~km} \text { of } \\
\text { wells }\end{array}$ & 2 & + & $0.01(0.07)$ & 0 & 1 \\
\hline FacQtrsWit & $\begin{array}{l}\text { Total number of } \\
\text { quarters within } \\
\text { last } 3 \text { years } \\
\text { where all sites } \\
\text { within } 0.5 \mathrm{~km} \\
\text { buffer have } \\
\text { failed to comply } \\
\text { with EPA } \\
\text { environmental } \\
\text { standards }\end{array}$ & 1 and 2 & + & $0.05(0.66)$ & 0 & 12 \\
\hline Percentairport & $\begin{array}{l}\text { Percent of sites } \\
\text { as airports } \\
\text { within } 1 \mathrm{~km} \text { of } \\
\text { wells }\end{array}$ & 3 & + & $0.01(0.07)$ & 0 & 1 \\
\hline Percentlandfill & $\begin{array}{l}\text { Percent of sites } \\
\text { as landfills } \\
\text { within } 1 \mathrm{~km} \text { of } \\
\text { wells }\end{array}$ & 3 & + & $0.03(0.17)$ & 0 & 1 \\
\hline Percentelectroplating & $\begin{array}{l}\text { Percent of sites } \\
\text { as electroplating } \\
\text { within } 1 \mathrm{~km} \\
\text { of wells }\end{array}$ & 3 & + & $0.01(0.12)$ & 0 & 1 \\
\hline Percentallothers & $\begin{array}{l}\text { Percent of sites } \\
\text { as all other } \\
\text { industry types } \\
\text { within } 1 \mathrm{~km} \text { of } \\
\text { wells }\end{array}$ & 3 & + & $0.93(0.25)$ & 0 & 1 \\
\hline Airport & $\begin{array}{l}\text { Number of sites } \\
\text { as airports } \\
\text { within } 1 \mathrm{~km} \text { of } \\
\text { wells }\end{array}$ & 4 & + & $0.01(0.11)$ & 0 & 2 \\
\hline Landfill & $\begin{array}{l}\text { Number of sites } \\
\text { as landfills } \\
\text { within } 1 \mathrm{~km} \text { of } \\
\text { wells }\end{array}$ & 4 & + & $0.07(0.53)$ & 0 & 10 \\
\hline Electroplating & $\begin{array}{l}\text { Number of sites } \\
\text { as electroplating } \\
\text { within } 1 \mathrm{~km} \\
\text { of wells }\end{array}$ & 4 & + & $0.02(0.16)$ & 0 & 2 \\
\hline
\end{tabular}




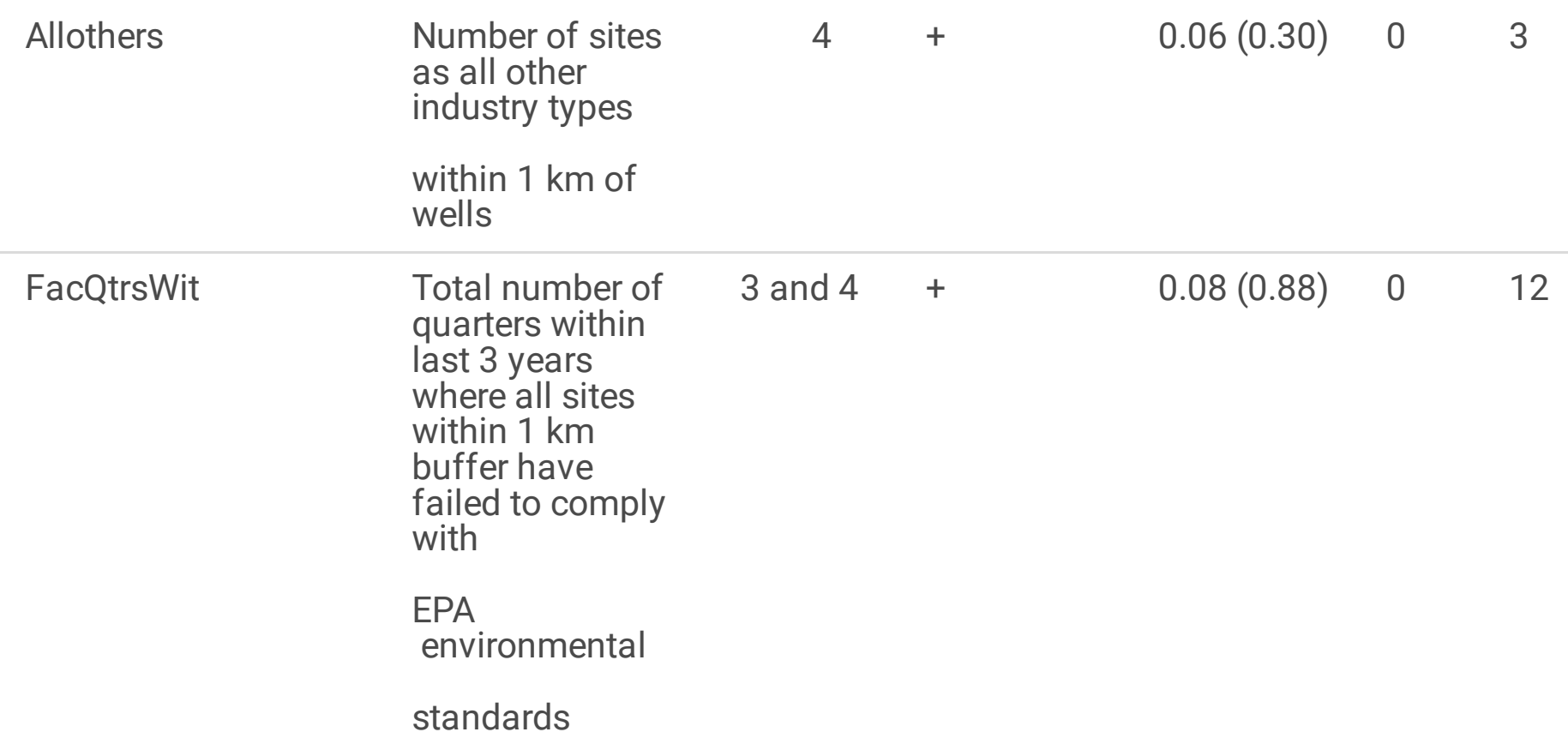

Model 1: $0.5 \mathrm{~km}$ buffer, percent of industry sites

Model 2: $0.5 \mathrm{~km}$ buffer, number of industry sites

Model 3: $1 \mathrm{~km}$ buffer, percent of industry sites

Model 4: $1 \mathrm{~km}$ buffer, number of industry site

Table 3: Michigan Industries within defined buffer sizes $(0.1,0.5,1.0 \mathrm{~km})$ of drinking water wells with detected PFAS concentrations. For total number of identified industrial sites in Michigan, $n=2,696^{n}$. 

NAICS
Industry Classification
$0.1 \mathrm{~km}$
$0.5 \mathrm{~km}$
$1.0 \mathrm{~km}$

Code

313320 Fabric Coating Mills $(n=9)$

$\begin{array}{lll}0 & 0 & 0\end{array}$

313310 Textile and Fabric Finishing Mills $(n=4)$

0

0

0

336310 Motor Vehicle Gasoline Engine and Engine

0

0

0

Parts Manufacturing $(\mathrm{n}=48)$

324110 Petroleum Refineries $(n=11)$

0

0

0

325320

Pesticide and Other Agricultural Chemical

0

0

0

Manufacture

$(n=10)$

325992

Photographic Film, Paper, Plate, and

Chemical Manufacture $(n=7)$

326112 Plastics Packaging Film and Sheet

(including Laminated) Manufacture $(n=9)$

325211 Plastics Material and Resin Manufacture (n

$=116$ )

316110 Leather and Hide Tanning and Finishing (n $=7$ )

322220

Paper Bag and Coated and Treated Paper Manufacture

0

0

0

$(n=14)$

332813 Electroplating, Plating, Polishing, Anodizing, and Coloring

0

0

0

$(\mathrm{n}=317)$

314110 Carpet and Rug Mills $(n=2)$

0

1

2

812310, Dry Cleaning and Laundry Services $(n=133)$

812320

325199 All Other Basic Organic Chemical

Manufacture $(n=70)$

0

0

0

\begin{tabular}{|ll} 
& Manufacture $(\mathrm{n}=70)$ \\
325510 & Paint and Coating Manufacture $(\mathrm{n}=104)$ \\
323111 & $\begin{array}{l}\text { Commercial Printing (except Screen and } \\
\text { Books })(n=102)\end{array}$ \\
\hline
\end{tabular}

0

1

2

313210 Broadwoven Fabric Mills, Manmade Fibers and Silk $(n=4)$ 


$$
(n=14)
$$

\begin{tabular}{lllll}
\hline 488119 & Airports $(\mathrm{n}=69)$ & 0 & 0 & 3 \\
\hline 322121 & Paper Mills $(\mathrm{n}=33)$ & 0 & 1 & 2 \\
332999 & Metal Foil and Leaf Manufacture $(\mathrm{n}=205)$ & 0 & 1 & 6 \\
324191 & Lubricating Oils and Greases $(\mathrm{n}=46)$ & 0 & 1 & 1 \\
\hline 562212 & Solid Waste Landfill $(\mathrm{n}=1373)$ & 0 & 3 & 8 \\
\hline 928110 & Department of Defense Sites $(\mathrm{n}=7)$ & 0 & 0 & 0 \\
323120 & Support Activities for Printing $(\mathrm{n}=13)$ & 0 & 0 & 0 \\
322219 & $\begin{array}{l}\text { Sanitary Food Containers, Except Folding }(\mathrm{n} \\
=3)\end{array}$ & 0 & 0 & 0
\end{tabular}

\begin{tabular}{|c|c|c|c|c|}
\hline 325611 & $\begin{array}{l}\text { Perfumes, Cosmetics, and other Toilet } \\
\text { Preparations }(n=46)\end{array}$ & 0 & 0 & 0 \\
\hline 333249 & $\begin{array}{l}\text { Surgical and Medical Instruments and } \\
\text { Apparatus }(n=45)\end{array}$ & 0 & 0 & 0 \\
\hline 325612 & $\begin{array}{l}\text { Specialty Cleaning, Polishing, and } \\
\text { Sanitation Preparations } \\
(\mathrm{n}=27)\end{array}$ & 0 & 0 & 0 \\
\hline
\end{tabular}

$333318 \begin{aligned} & \text { Service Industry Machinery, Not Elsewhere } \\ & \text { Classified }(n=16)\end{aligned} \quad 0 \quad 0 \quad 0$

\begin{tabular}{|c|c|c|c|c|}
\hline 334413 & $\begin{array}{l}\text { Semiconductor and Related Device } \\
\text { Manufacture }(n=20)\end{array}$ & 0 & 0 & 0 \\
\hline 326113 & $\begin{array}{l}\text { Unsupported Plastics Film and Sheet }(\mathrm{n}= \\
\text { 19) }\end{array}$ & 0 & 0 & 0 \\
\hline 314999 & Waterproof Outerwear $(n=8)$ & 0 & 0 & 0 \\
\hline \multicolumn{2}{|c|}{ Total $(n=2696)$} & 0 & 8 & 26 \\
\hline
\end{tabular}

${ }^{n} n=$ number of industries of each code in Michigan. Some sites classified as multiple industries on list and are counted totals for each industry, but once in grand total.

Table 4: Probit regression analysis results for $1 \mathrm{~km}$ buffers $(n=1081)$. 


\begin{tabular}{|c|c|c|c|c|c|c|}
\hline Variable & $\begin{array}{l}\text { Model 1: } \\
1 \text { km } \\
\text { buffer, } \\
\% \text { sites } \\
\text { Wald Chi- } \\
\text { Square }\end{array}$ & B & Sig. & $\begin{array}{l}\text { Model 2: } 1 \\
\text { km buffer, } \\
\text { \#sites } \\
\text { Wald } \\
\text { ChiSquare }\end{array}$ & B & Sig. \\
\hline (Intercept) & 0.027 & 0.062 & 0.869 & 17.743 & 0.791 & 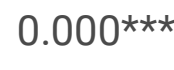 \\
\hline Bedrock & 0.077 & 0.033 & 0.782 & 0.009 & 0.011 & 0.924 \\
\hline Welldepth & 27.196 & 0.007 & $0.000 \star \star \star$ & 27.190 & 0.007 & 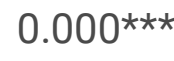 \\
\hline Welldepthsq & 19.258 & $\begin{array}{l}-9.900 * 10^{-} \\
6\end{array}$ & $0.000 * \star \star *$ & 19.148 & $\begin{array}{l}-9.853 * 10^{-} \\
6\end{array}$ & $0.000 * * *$ \\
\hline Landcover & 1.291 & 0.155 & 0.256 & 1.221 & 0.150 & 0.269 \\
\hline Soildrainage & 7.758 & -0.384 & $0.005^{\star * \star}$ & 7.771 & -0.382 & $0.005^{\star * *}$ \\
\hline $\begin{array}{l}\text { Percentairport/ } \\
\text { Airport }\end{array}$ & 0.036 & -0.129 & 0.850 & 2.669 & -0.603 & 0.102 \\
\hline $\begin{array}{l}\text { Percentlandfill/ } \\
\text { Landfill }\end{array}$ & 1.626 & 0.552 & 0.202 & 0.109 & 0.035 & 0.741 \\
\hline $\begin{array}{l}\text { Percentelectroplating/ } \\
\text { Electroplating }\end{array}$ & 2.987 & 2.150 & $0.084^{*}$ & 1.104 & 0.549 & 0.293 \\
\hline $\begin{array}{l}\text { Percentallothers/ } \\
\text { Allothers }\end{array}$ & 4.924 & 0.735 & $0.026 * \star$ & 0.893 & -0.172 & 0.345 \\
\hline \multirow[t]{2}{*}{ FacQtrsWit } & 0.127 & -0.021 & 0.722 & 0.101 & -0.018 & 0.751 \\
\hline & $\begin{array}{l}\text { Wald Chi- } \\
\text { Square }\end{array}$ & $\begin{array}{l}\text { Degrees } \\
\text { of } \\
\text { Freedom }\end{array}$ & Sig. & $\begin{array}{l}\text { Wald Chi- } \\
\text { Square }\end{array}$ & $\begin{array}{l}\text { Degrees } \\
\text { of } \\
\text { Freedom }\end{array}$ & Sig. \\
\hline Omnibus test & 44.864 & 10 & 0.000 & 40.760 & 10 & 0.000 \\
\hline Observations & 1081 & & & & & \\
\hline
\end{tabular}

$*, * \star, * * *$ indicates statistical signficance at $p \leq 0.10, p \leq 0.05$, and $p \leq 0.01$ respectively

Table 5: Probit regression analysis results for $0.5 \mathrm{~km}$ buffers $(n=1081)$. 


\begin{tabular}{|c|c|c|c|c|c|c|}
\hline \multirow[t]{2}{*}{ Variable } & $\begin{array}{l}\text { Model 3: } 0.5 \\
\text { km buffer, \% } \\
\text { sites }\end{array}$ & B & Sig. & $\begin{array}{l}\text { Model 4: } 0.5 \\
\text { km buffer, } \\
\text { \#sites }\end{array}$ & B & \multirow[t]{2}{*}{ Sig. } \\
\hline & $\begin{array}{l}\text { Wald Chi- } \\
\text { Square }\end{array}$ & & & $\begin{array}{l}\text { Wald Chi- } \\
\text { Square }\end{array}$ & & \\
\hline (Intercept) & 18.050 & 0.793 & $0.000 * \star *$ & 17.973 & 0.792 & $0.000 * \star \star$ \\
\hline Bedrock & 0.104 & 0.038 & 0.747 & 0.100 & 0.037 & 0.752 \\
\hline Welldepth & 26.119 & 0.007 & $0.000 \star \star \star$ & 26.106 & 0.007 & $0.000 * \star \star *$ \\
\hline \multirow[t]{2}{*}{ Welldepthsq } & 18.241 & $-9.589 * 10^{-}$ & $0.000 * * *$ & 18.239 & $-9.596 * 10^{-}$ & $0.000 * * *$ \\
\hline & & \multicolumn{2}{|l|}{6} & & \multicolumn{2}{|l|}{6} \\
\hline Landcover & 1.054 & 0.139 & 0.305 & 1.062 & 0.139 & 0.303 \\
\hline Soildrainage & 7.437 & -0.371 & $0.006 * \star \star$ & 7.508 & -0.373 & $0.006^{* * *}$ \\
\hline $\begin{array}{l}\text { Percentlandfill/ } \\
\text { Landfill }\end{array}$ & 0.421 & -0.310 & 0.516 & 0.151 & -0.107 & 0.697 \\
\hline $\begin{array}{l}\text { Percentmetalfoil/ } \\
\text { Metalfoil }\end{array}$ & 0.524 & -0.456 & 0.469 & 0.520 & -0.454 & 0.471 \\
\hline \multirow[t]{2}{*}{ FacQtrsWit } & 0.937 & -0.062 & 0.333 & 0.932 & -0.062 & 0.334 \\
\hline & $\begin{array}{l}\text { Wald Chi- } \\
\text { Square }\end{array}$ & $\begin{array}{l}\text { Degrees } \\
\text { of } \\
\text { Freedom }\end{array}$ & Sig. & $\begin{array}{l}\text { Wald Chi- } \\
\text { Square }\end{array}$ & $\begin{array}{l}\text { Degrees } \\
\text { of } \\
\text { Freedom }\end{array}$ & Sig. \\
\hline Omnibus test & 37.040 & 8 & 0.000 & 36.783 & 8 & 0.000 \\
\hline Observations & \multicolumn{6}{|l|}{1081} \\
\hline
\end{tabular}




\begin{tabular}{|c|c|c|c|c|}
\hline Well Location City/Town & Cluster/Outlier Type & Moran's I index value & Z-score & p-value ${ }^{1}$ \\
\hline Plainwell & High-high & 0.000036 & 1.390 & 0.03 \\
\hline Kalamazoo & High-high & 0.00014 & 2.813 & 0.012 \\
\hline Plainwell & High-high & 0.000105 & 1.684 & 0.05 \\
\hline Parchment & High-low & -0.0009 & 1.842 & 0.048 \\
\hline Houghton & Low-low & 0.000002 & 0.272 & 0.004 \\
\hline Sherman Township & Low-low & 0.000002 & 0.314 & 0.02 \\
\hline Richmond Township & Low-low & 0.023118 & 0.140 & 0.01 \\
\hline Richmond Township & Low-low & 0.023118 & 0.174 & 0.01 \\
\hline Marquette & Low-low & 0.00003 & 0.190 & 0.01 \\
\hline KL Sawyer AFB & Low-low & 0.000004 & 0.407 & 0.002 \\
\hline Escanaba & Low-low & 0.000004 & 0.321 & 0.018 \\
\hline Gladstone & Low-low & 0.000004 & 0.363 & 0.006 \\
\hline Kawkawlin & Low-low & 0.000008 & 0.263 & 0.016 \\
\hline Northport & Low-low & 0.000003 & 0.227 & 0.046 \\
\hline Parkwood Village & Low-low & 0.000006 & 0.706 & 0.028 \\
\hline Climax & Low-high & -0.000058 & -2.904 & 0.032 \\
\hline Delton & Low-high & -0.000034 & -2.438 & 0.046 \\
\hline Gun Plain Township & Low-high & -0.000124 & -2.904 & 0.032 \\
\hline Lockport Township & Low-high & -0.00003 & -1.890 & 0.044 \\
\hline Otsego & Low-high & -0.000061 & -1.594 & 0.042 \\
\hline Portage & Low-high & -0.000058 & -3.485 & 0.012 \\
\hline Kalamazoo & Low-high & -0.000049 & -2.159 & 0.048 \\
\hline Kalamazoo & Low-high & -0.000146 & -3.898 & 0.032 \\
\hline
\end{tabular}

${ }^{1}$ Threshold for significance was defined at $p$-values of 0.05 or below.

\section{Figures}




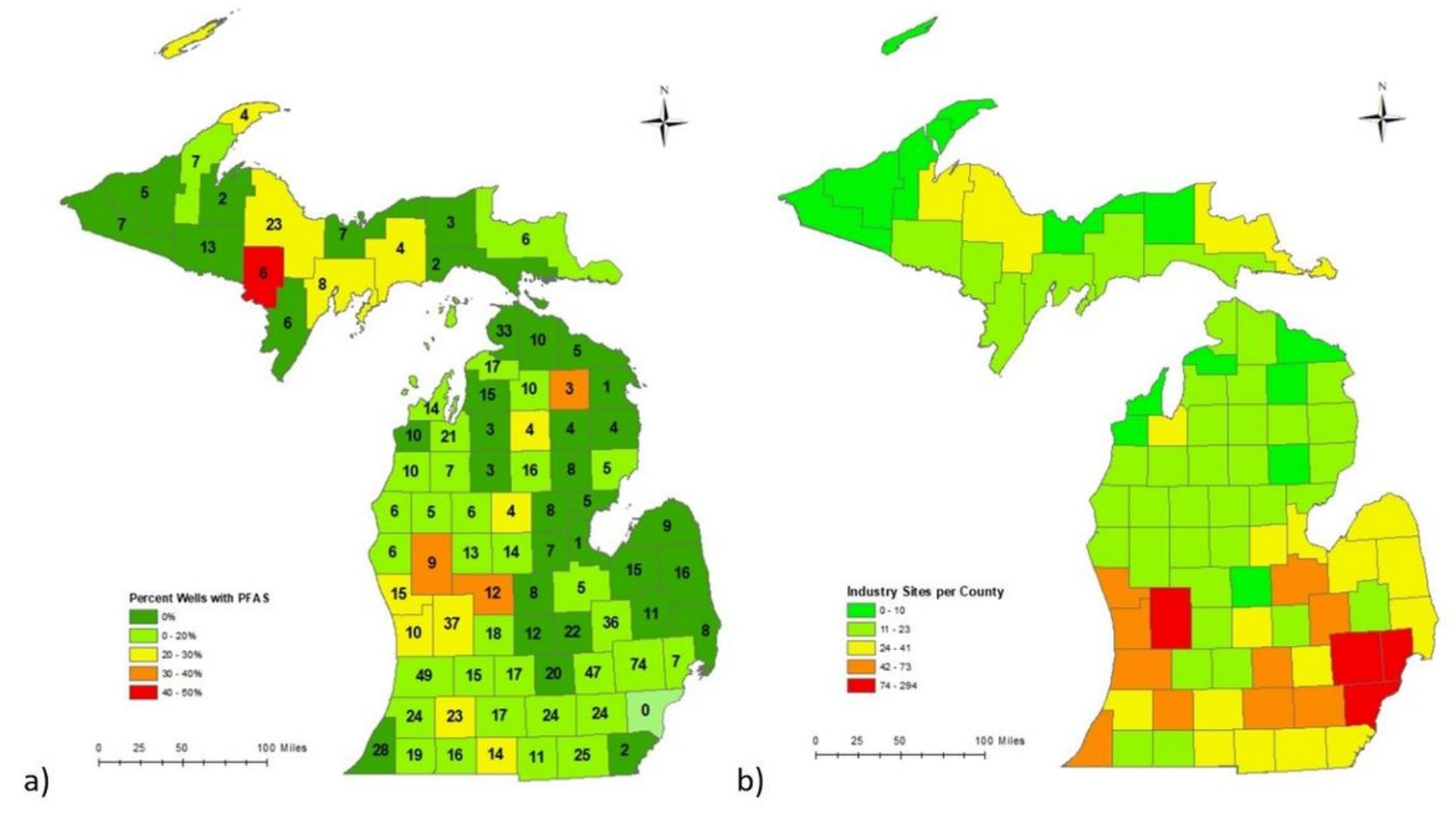

\section{Figure 1}

(a) Total groundwater wells per county, indicated by the numerical value on each county, and percentage of wells with PFAS in each county as shown by color scale. (b) Number of PFAS industry sites in Michigan by county. 


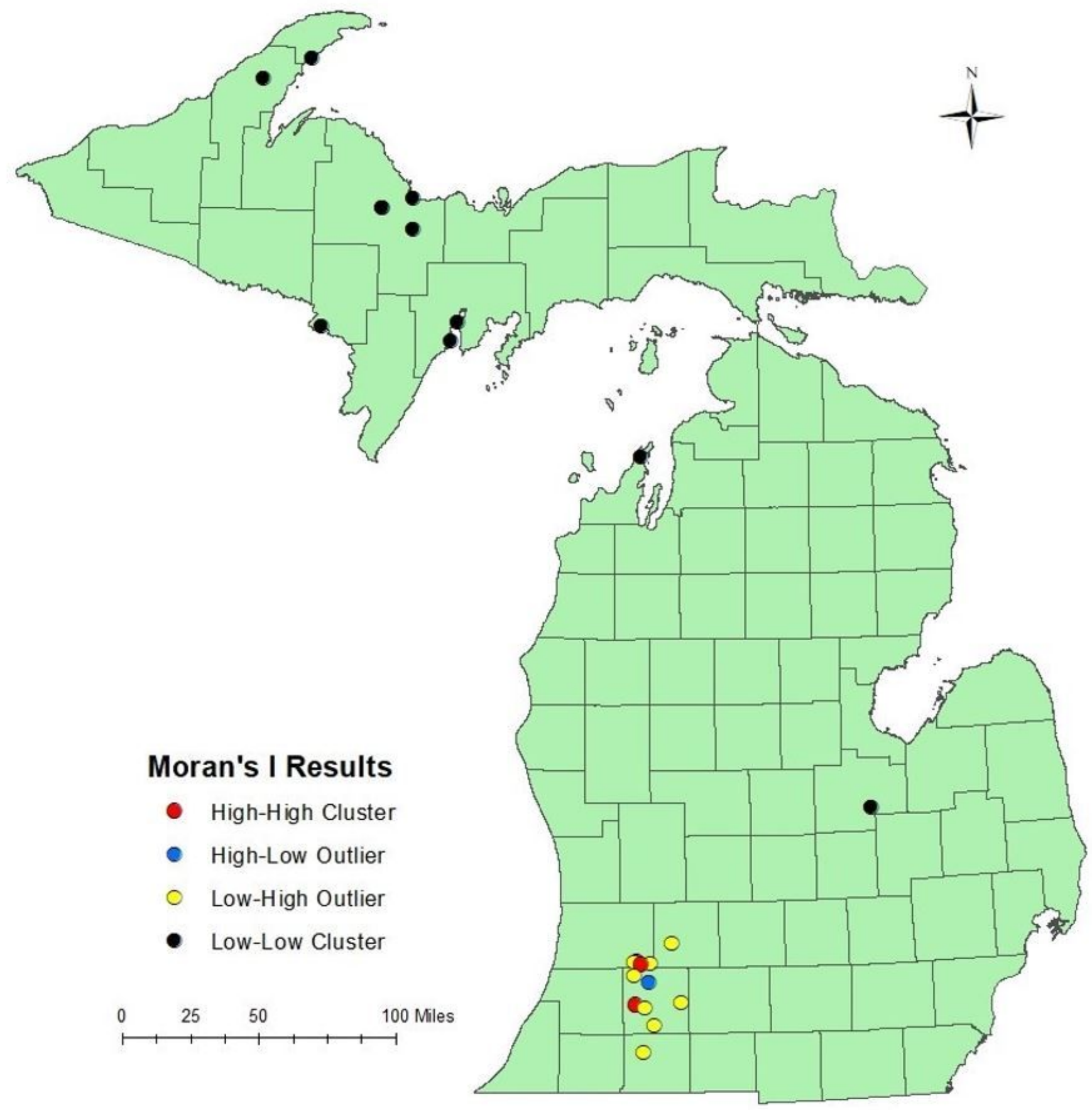

Figure 2

Local Moran's I for PFAS clusters in Michigan (detected wells only). 